\title{
Rancang Bangun Alat Pendeteksi Kondisi Cuaca Kota Balikpapan Menggunakan Global Navigation Satellite System (GNSS) Wind Turbine
}

\author{
Budiani Fitria Endrawati ${ }^{1}$, Adhe Yusphie ${ }^{2}$, Arum Prastiyo Putri ${ }^{3}$, Azam Fadhil A $^{4}$, Mohammad \\ Saiful $\mathbf{R}^{5}$, Fadli Robiandi ${ }^{6}$ \\ ${ }^{1}$ Program Studi Teknik Industri, Institut Teknologi Kalimantan, Balikpapan. Email: wati@itk.ac.id \\ ${ }^{2}$ Program Studi Teknik Mesin, Institut Teknologi Kalimantan, Balikpapan. Email: 03151005@itk.ac.id \\ ${ }^{3}$ Program Studi Teknik Sipil, Institut Teknologi Kalimantan, Balikpapan. Email:07151005@itk.ac.id \\ ${ }^{4}$ Program Studi Sistem Informasi, Institut Teknologi Kalimantan, Balikpapan. Email: 10161022@itk.ac.id \\ ${ }^{5}$ Program Studi Teknik Elektro, Institut Teknologi Kalimantan, Balikpapan. Email: 04151031@itk.ac.id \\ ${ }^{6}$ Program Studi Fisika, Institut Teknologi Kalimantan, Balikpapan. Email: fadlirobiandi@itk.ac.id
}

\begin{abstract}
Balikpapan is one of the cities in East Kalimantan with unique characteristic of the region. The characteristics of the region and the height of the area from the sea surface of the city of Balikpapan is one of the factors, therefore need to be designed a tool to detect weather especially in Balikpapan city. The device design using Global Navigation Satellite System (GNSS) Wind Turbine. The measurement results are based on temperature, humidity and wind speed. From the measurement of temperature, humidity and wind speed obtained an average of $30.97^{\circ} \mathrm{C}$; $73.49 \%$ and $2.91 \mathrm{~m} / \mathrm{s}$. According to method World Meteorological Organization, temperature, humidity and wind speed data is accepted.
\end{abstract}

Keywords: Weather Detector, GNSS, Wind Turbine.

\begin{abstract}
Abstrak
Balikpapan merupakan salah satu kota di Kalimantan Timur dengan karakteristik wilayah cukup unik. Karakteristik wilayah serta ketinggian daerah dari permukaan air laut kota Balikpapan merupakan salah satu faktor yang berpengaruh pada unsur-unsur curah hujan dan tinggi rendahnya suhu yang ada, sehingga mempengaruhi cuaca serta iklim kota Balikpapan yang tidak menentu, oleh karena itu perlu dirancang sebuah alat untuk mendeteksi cuaca terutama di kota Balikpapan. Perancangan alat menggunakan Global Navigation Satellite System (GNSS) Wind Turbine. Hasil pengukuran dilakukan berdasarkan pengukuran suhu, kelembaban dan kecepatan angin. Dari hasil pengukuran suhu, kelembaban dan kecepatan angin didapatkan rata-rata sebesar $30,97^{\circ} \mathrm{C} ; 73,49 \%$ dan 2,91 m/s. Berdasarkan metode World Meteorological Organization, data suhu, kelembaban dan kecepatan angin dapat diterima.
\end{abstract}

Kata Kunci: Pendeteksi Cuaca, GNSS, Wind Turbine.

\section{Pendahuluan}

Balikpapan merupakan salah satu kota di Kalimantan Timur dengan karakteristik wilayah cukup unik. Balikpapan memiliki dua musim yaitu musim kemarau dan musim hujan. Topografi Balikpapan hampir seluruhnya berbukit (85\%), terutama dibagian utara wilayah kota. Ketinggian wilayah kota Balikpapan dari permukaan air laut berkisar 0-80 meter (Badan Perencanaan Pembangunan Daerah, 2015).

Berdasarkan data Badan Perencanaan Pembangunan Daerah (2015), kondisi topografi wilayah kota Balikpapan terdiri dari daerah pesisir dengan daratan yang berbukit, potensi angin dapat dimanfaatkan. 
Karakteristik wilayah serta ketinggian daerah dari permukaan air laut kota Balikpapan merupakan salah satu faktor yang berpengaruh pada unsur-unsur curah hujan dan tinggi rendahnya suhu yang ada, sehingga mempengaruhi cuaca serta iklim kota Balikpapan yang tidak menentu.

Menurut Zeta (2016), pemantauan kondisi cuaca pada suatu lingkungan saat ini dirasa sangat penting karena perubahan cuaca yang tak menentu setiap harinya. Informasi tentang kondisi cuaca dari beberapa tempat dapat dijadikan prediksi kondisi cuaca beberapa hari mendatang.

Kondisi cuaca dapat didorong oleh suhu dan kelembaban yang berbeda antar wilayah tertentu, begitu pula dengan kondisi cuaca kota Balikpapan. Alat pendeteksi cuaca yang ada saat ini hanya dimiliki oleh BMKG, dimana alat tersebut memiliki kendala dari segi penggunaan listrik. Alat BMKG masih menggunakan listrik PLN, oleh sebab itu perlu dirancang sebuah alat pendeteksi dimana penggunaan listriknya tidak bergantung pada listrik PLN, tetapi dapat menggunakan listrik dari angin.

Alat yang dibuat dalam penelitian ini menggunakan Global Navigation Satellite System (GNSS) Wind Turbine. GNSS merupakan teknologi untuk menentukan posisi atau lokasi serta waktu. Umumnya, jenis GNSS yang digunakan adalah Global Positioning System (GPS). Sistem satelit navigasi GPS adalah milik Amerika Serikat dimana diluncurkan pertama kali tahun 1978, akan tetapi jenis GNSS yang digunakan pada penelitian ini adalah Global Navigation Satellite System (GLONASS).

GLONASS adalah jenis sistem navigasi milik Rusia. Menurut Azmi (2012), GLONASS merupakan sistem satelit navigasi yang telah beroperasi penuh pada skala global, memiliki 24 satelit yang mengorbit dan dalam kondisi baik. Perbandingan antara GPS dan GLONASS adalah GLONASS memiliki sistem kerja yang tidak jauh dengan GPS, hanya saja GLONASS bisa mencapai 7-10 meter dibandingkan GPS yang hanya mencapai 3-4 meter (Gazeta, 2014), sedangkan wind turbine yang digunakan berdaya 400 watt $12 / 24 \mathrm{~V}$.

Tujuan dari penelitian ini adalah untuk merancang alat untuk mengetahui bagaimana kondisi cuaca kota Balikpapan berdasarkan pengukuran suhu, kelembaban dan kecepatan angin. Perancangan alat meliputi perangkat keras (hardware).

\section{Metode}

\subsection{Lokasi dan Waktu}

Lokasi pengujian alat dilakukan di pesisir pantai Monumen Perjuangan Rakyat (Monpera) Balikpapan selama 4 hari. Lokasi pesisir pantai Monpera dipilih karena lokasi tersebut memiliki tingkat halangan terhadap angin dan kelembaban sedikit dibandingkan lokasi yang lain.

\subsection{Komponen Alat}

Komponen alat yang digunakan dalam penelitian ini, ditunjukkan pada Tabel 1.

$\begin{array}{ll}\text { No } & \text { Komponen Alat } \\ 1 & \text { Anemometer } \\ 2 & \text { Arduino Uno R3 } \\ 3 & \text { Sensor DHT-11 } \\ 4 & \text { Sensor FC-37 }\end{array}$

\section{Tabel 1. Komponen Alat}

Fungsi

Mengukur kecepatan angin

Sebagai otak dari sistem kinerja

Sebagai pengukur suhu dan kelembaban

Sebagai sensor hujan yang dapat mendeteksi hujan

berdasarkan pada tetesan hujan 


$\begin{array}{ll}\text { No } & \text { Komponen Alat } \\ 5 & \text { Micro SD } \\ 6 & \text { Real Time Clock (RTC) DS1302 } \\ 7 & \text { GNSS Glonass U Blox } 7 \\ 8 & \text { Wind Turbine } \\ & \\ 9 & \text { Inverter DC to AC } 150 \mathrm{~W} \\ 10 & \text { Accu 12V 3,5A } \\ 11 & \text { Buzzer }\end{array}$

\author{
Fungsi \\ Penyimpan data \\ Sebagai penanda waktu untuk setiap data yang didapatkan \\ Penanda lokasi pengambilan data \\ Pengkonversi energi angin menjadi energi listrik, untuk \\ dijadikan energi utama dari alat yang digunakan \\ Pengubah tegangan 12 volt DC ke 220 volt AC dengan \\ keluaran daya sekitar $150 \mathrm{~W}$ \\ Penyimpan energi listrik (tegangan DC) \\ Pengubah getaran listrik menjadi getaran suara
}

\subsection{Perancangan Alat}

Langkah pertama dalam rancang bangun alat pendeteksi cuaca adalah pemasangan wind turbine dengan tiang penyangga setinggi 3 meter, lalu penyambungan kabel pada wind charge controller sebagai penstabil arus DC yang akan masuk ke dalam aki sebanyak 2 buah dan diubah menjadi arus AC dengan menggunakan inverter untuk menghidupkan 2 buah Arduino serta seluruh sensor dan modul. Skematik sistem Arduino Uno R3 dapat dilihat pada Gambar 1.

Setiap sensor dihubungkan ke arduino dengan jumper sesuai dengan skema di program. Bahasa pemrograman menggunakan bahasa pemrograman C. Arduino Uno (1) terpasang sensor DHT-11 (sensor suhu dan kelembaban) serta sensor FC-37 (sensor hujan) yang dilengkapi dengan LED merah (kondisi hujan) dan LED biru (kondisi cerah) serta buzzer yang akan berbunyi jika kondisi hujan.

Arduino Uno (2), terpasang anemometer yang berfungsi untuk mengukur kecepatan angin dan datanya tersimpan pada micro sd yang telah dilengkapi Real Time Clock (RTC). Listrik yang digunakan, didapatkan dari angin pantai Monpera yang dikonversikan oleh turbin angin 400 watt $12 / 24 \mathrm{~V}$ untuk disimpan kedalam Accu 12V 3,5Ah. Diagram alir perancangan alat, dapat dilihat pada Gambar 2.

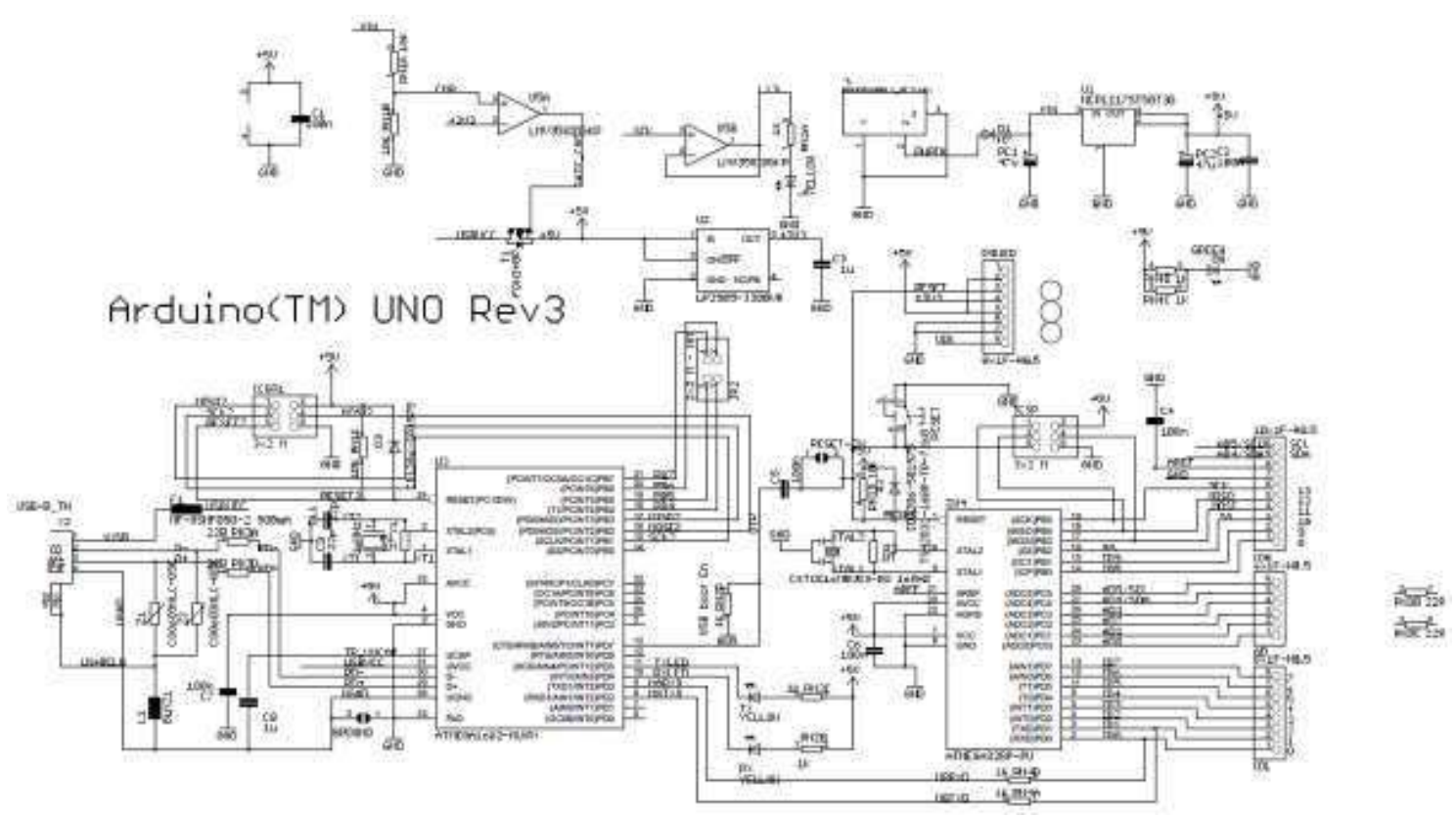

Gambar 2. Skematik Sistem Arduino Uno R3 


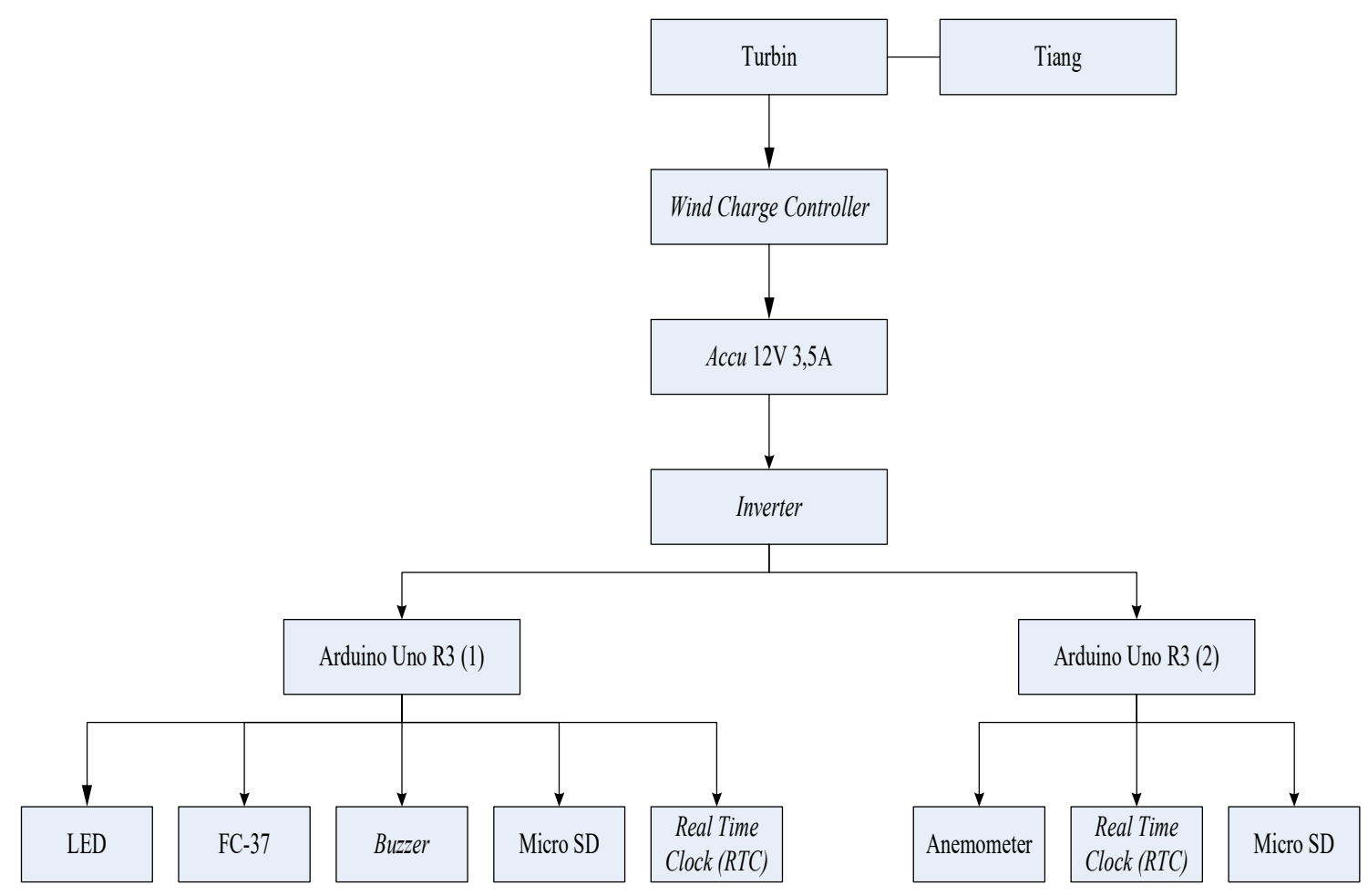

Gambar 3. Diagram Alir Perancangan Alat

\subsection{Metode World Meteorological Organization Instruments and Observing}

World Meteorological Organization (WMO) merupakan badan meteorologi internasional sehingga pengukuran suhu, kelembaban dan kecepatan angin yang dilakukan harus mengacu pada metode WMO. Pengambilan data berdasarkan standar National Meteorological Centres (NMCs). Standar yang dimiliki NMCs terdiri dari (World Meteorological Organization, 2011) :

1. Nowcasts yaitu standar pengambilan data yang dilakukan dalam kurun waktu 0-2 jam.

2. Very Short Range yaitu standar pengambilan data yang dilakukan dalam kurun waktu mencapai 12 jam.

3. Short Range yaitu standar pengambilan data yang dilakukan dalam kurun waktu diatas 12 jam dan mencapai 72 jam.

4. Medium Range yaitu standar pengambilan data yang dilakukan dalam kurun waktu diatas 72 jam dan mencapai 240 jam.

5. Extended Range yaitu standar pengambilan data yang dilakukan dalam kurun waktu diatas 10 hari dan mencapai 30 hari.

6. Long Range yaitu standar pengambilan data yang dilakukan dalam kurun waktu dari 30 hari hingga mencapai 2 tahun. Long Range dapat digolongkan beberapa jenis yaitu:
a. Pengambilan data dalam 1 bulan
b. Pengambilan data dalam 3 bulan
c. Pengambilan data dalam 1 musim 


\section{Hasil dan Pembahasan}

\subsection{Pengujian Alat}

Pengujian alat yang dilakukan adalah analisis uji coba pemilihan komponen alat terhadap kondisi cuaca pesisir pantai Monpera. Kondisi cuaca dikategorikan menjadi 3 kategori yaitu cuaca cerah, berawan dan hujan berdasarkan pengukuran suhu, kelembaban dan kecepatan angin.

Kondisi cuaca dikategorikan menjadi 3 kategori yaitu cuaca cerah, berawan dan hujan berdasarkan kondisi pesisir pantai Monpera saat pengujian alat. Cuaca cerah jika suhu $\geq 25^{\circ} \mathrm{C}$, kelembaban $<88 \%$, dan kecepatan angin cenderung naik. Cuaca dideteksi hujan jika suhu $\leq 25{ }^{\circ} \mathrm{C}$, kelembaban $\geq 88 \%$, dan kecepatan angin cenderung turun (World Meteorological Organization, 2011).

Uji coba alat dilakukan selama 8 jam secara manual, dimana data suhu, kelembaban dan kecepatan angin tersimpan secara otomatis di dalam micro sd, kemudian data yang telah diperoleh, diolah dan dibandingkan dengan standar National Meteorological Centres (NMCs). Dari hasil uji coba alat, menunjukan bahwa kondisi cuaca pesisir pantai Monpera adalah cerah. Hal ini didukung dengan indikator LED yang menunjukkan warna biru (kondisi cerah), seperti yang ditunjukkan pada Gambar 3 .

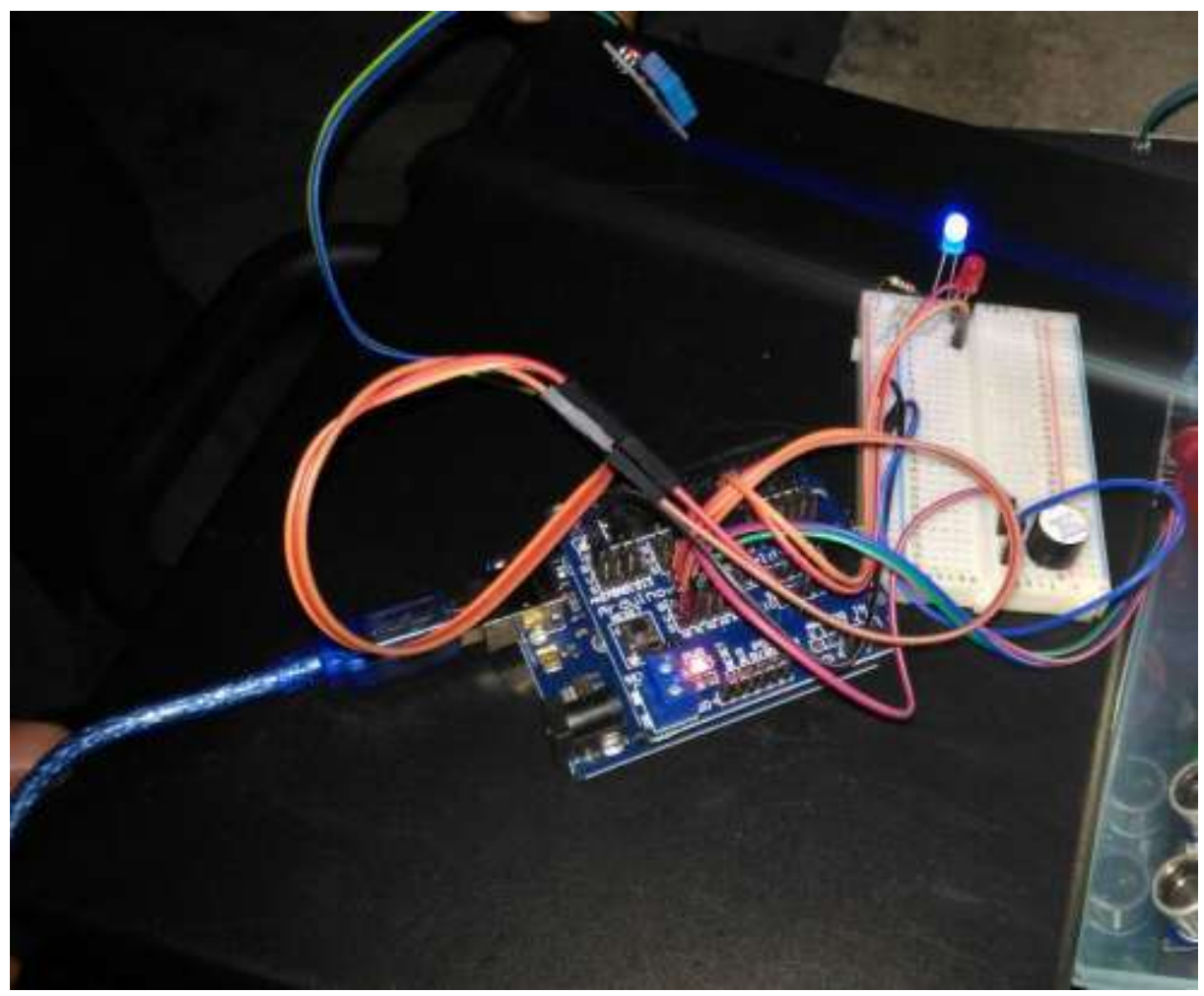

Gambar 4. Indikator LED

\subsection{Pengukuran Suhu, Kelembaban dan Kecepatan Angin}

\subsubsection{Pengukuran Suhu}

Pengukuran suhu dilakukan mulai dari pukul 10.00 WITA hingga pukul 18.00 WITA. Berdasarkan hasil pengamatan yang ditunjukkan pada Gambar 4, suhu yang dihasilkan cenderung stabil. Suhu terendah yang dihasilkan mencapai suhu $25^{\circ} \mathrm{C}$ pada pukul 17.45 dan suhu tertinggi mencapai $39^{\circ} \mathrm{C}$ yaitu pada pukul 10.34 dan pukul 12.13. Rata-rata suhu yang dihasilkan sebesar $30,97^{\circ} \mathrm{C}$. 


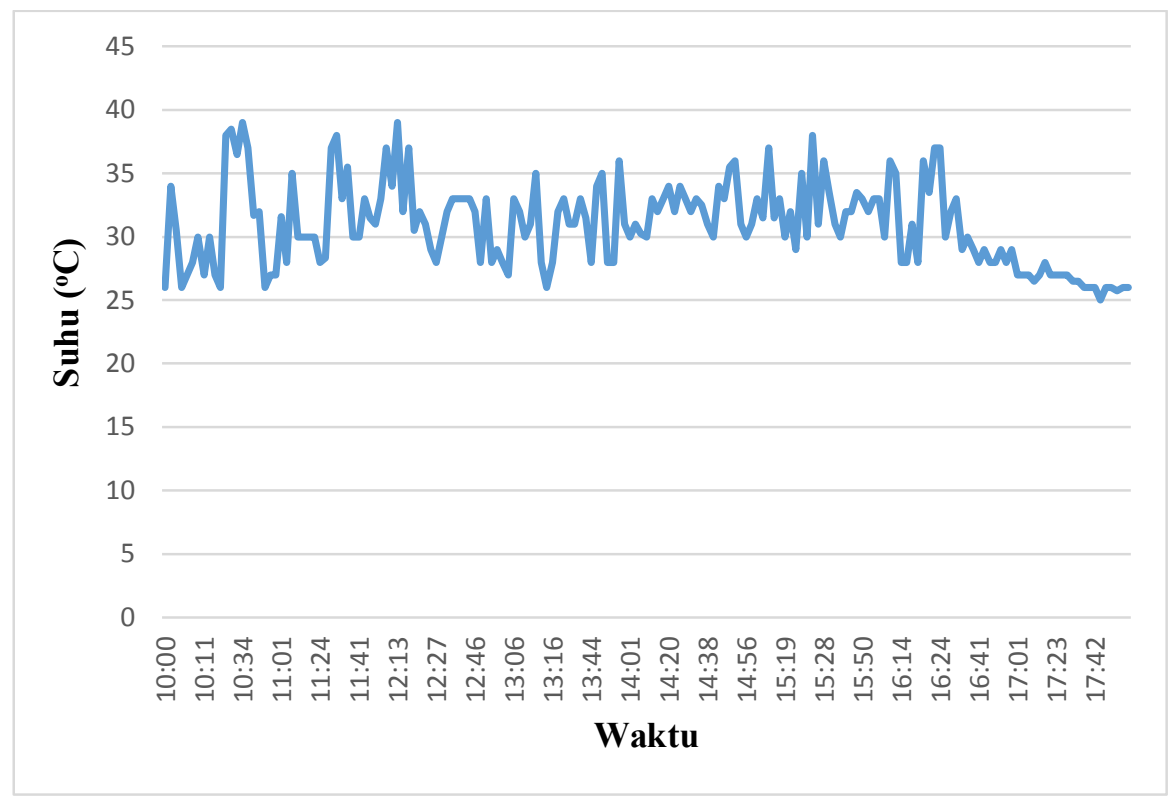

Gambar 5. Grafik Suhu

\subsubsection{Pengukuran Kelembaban}

Pengukuran kelembaban dilakukan mulai dari pukul 10.00 WITA hingga pukul 18.00 WITA. Berdasarkan hasil pengamatan yang ditunjukkan pada Gambar 5, kelembaban yang dihasilkan cenderung tidak stabil. Kelembaban terendah yang dihasilkan mencapai 54\% pada pukul 11.34 dan 12.11. Kelembaban tertinggi mencapai $93 \%$ yaitu pada pukul 10.00 dan pukul 10.48 . Rata-rata suhu yang dihasilkan sebesar $73,49 \%$.

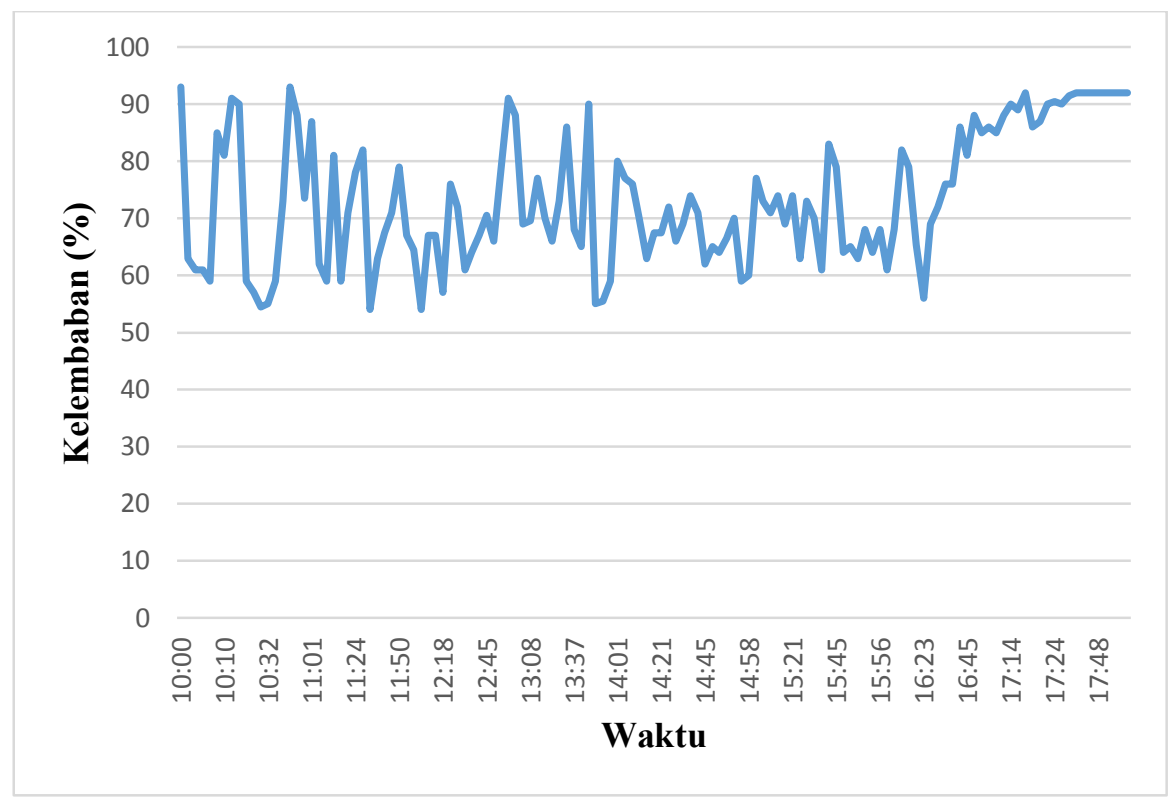

\section{Gambar 6. Grafik Kelembaban}

\subsubsection{Pengukuran Kecepatan Angin}

Pengukuran kecepatan angin dilakukan mulai dari pukul 10.00 WITA hingga pukul 18.00 WITA dengan rentang waktu sebesar 30 menit. Berdasarkan hasil pengamatan yang ditunjukkan pada Gambar 6, 
dinyatakan bahwa kecepatan angin pada tanggal tanggal 1 Juli 2017 cenderung rendah dan menurun hingga mencapai kecepatan terendah yaitu $0,09 \mathrm{~m} / \mathrm{s}$ pada pukul 18:00 WITA, sedangkan pada tanggal 3 Juli 2017 mencapai kecepatan tertinggi yaitu 5,73 m/s pukul 12:00 WITA. Pada tanggal 30 Juni 2017 dan 2 Juli 2017 memiliki kecepatan angin yang stabil. Secara keseluruhan, kecepatan angin terendah mencapai $0,09 \mathrm{~m} / \mathrm{s}$ dan kecepatan angin tertinggi mencapai $5,73 \mathrm{~m} / \mathrm{s}$. Rata-rata kecepatan angin yang dihasilkan sebesar $2,91 \mathrm{~m} / \mathrm{s}$.

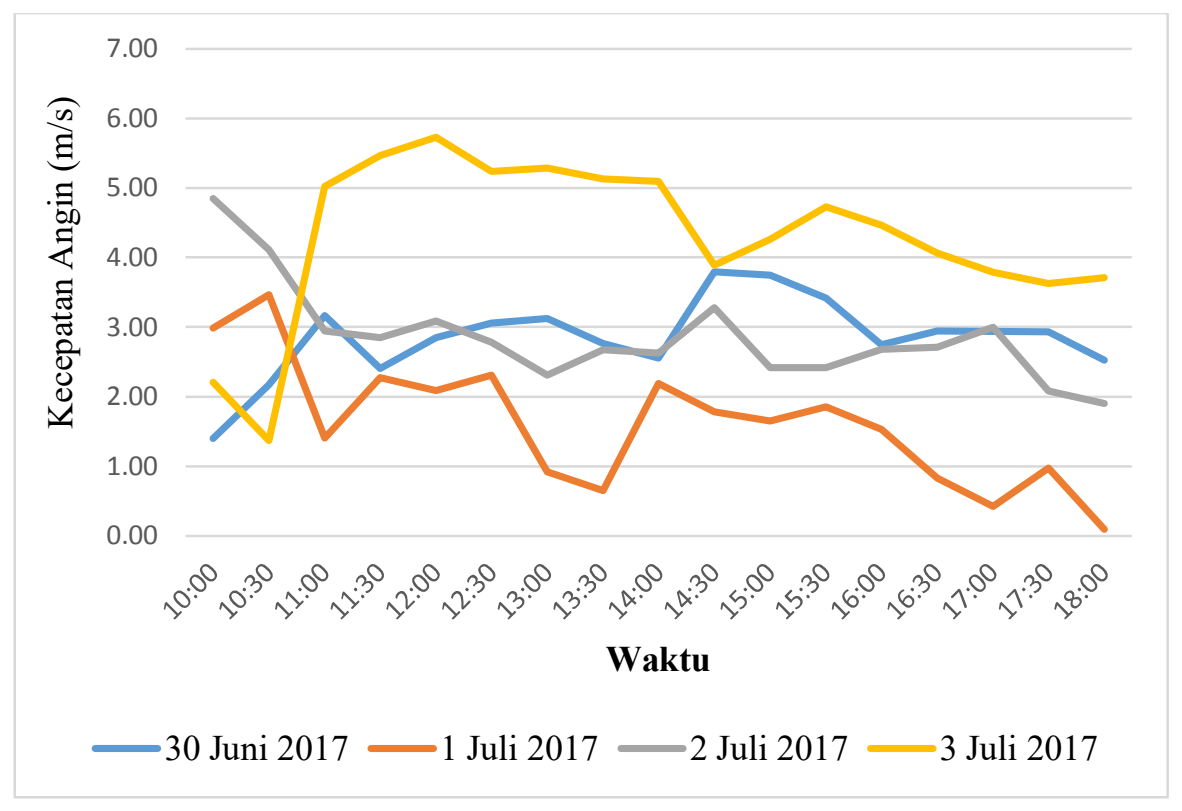

\section{Gambar 7. Grafik Kecepatan Angin}

\subsection{Analisa Hasil}

Data yang telah diperoleh, diolah kembali untuk mendapatkan nilai maksimal, nilai minimal dan nilai rata-ratanya untuk mengetahui kondisi cuaca, apakah sesuai dengan metode WMO atau tidak. Pada saat proses pengumpulan data, terdapat keterangan mengenai kondisi cuaca dari sensor FC37 serta indikator LED.

Hasil analisa data menunjukkan bahwa kondisi cuaca pantai Monpera adalah cerah dan telah sesuai dengan metode WMO, seperti yang disajikan pada Tabel 2. Hal ini didukung dengan kondisi real pantai Monpera bahwa kondisi cuaca adalah cerah, ditunjukkan pada Gambar 7.

Tabel 2. Hasil Analisa Data

\begin{tabular}{llllllllll}
\multicolumn{2}{l}{ Suhu $\left({ }^{\circ} \mathrm{C}\right)$} & \multicolumn{4}{c}{ Kelembaban $(\%)$} & \multicolumn{2}{c}{ Kecepatan Angin $(\mathrm{m} / \mathrm{s})$} & Kondisi Cuaca \\
Min & Maks & Rata-rata & Min & Maks & Rata-rata & Min & Maks & Rata-rata & \\
25 & 39 & 30,97 & 54 & 93 & 73,49 & 0,09 & 5,73 & 2,91 & Cerah
\end{tabular}




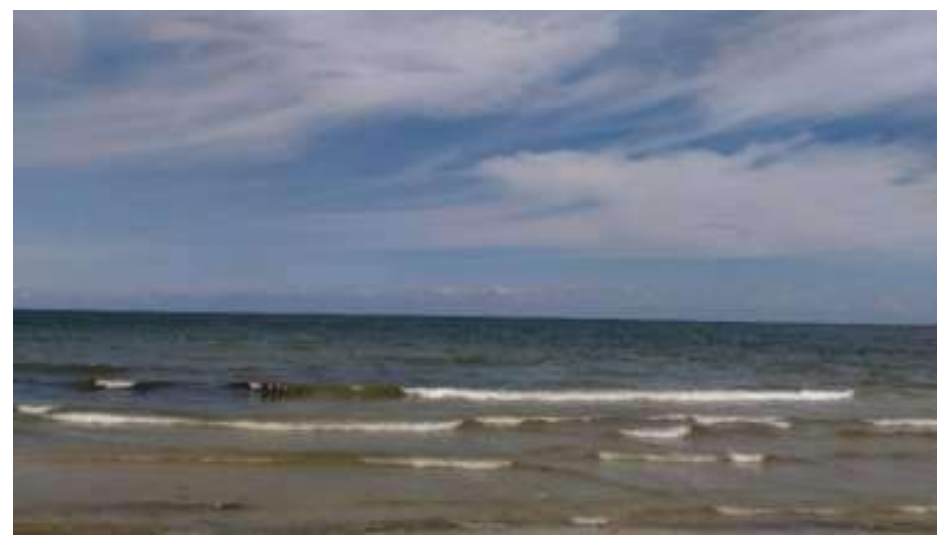

Gambar 8. Kondisi Real Pantai Monpera

Dari hasil analisa data yang telah dilakukan, menunjukkan bahwa data yang diperoleh telah sesuai dengan metode WMO. Hal ini menunjukkan bahwa rancang bangun alat dapat digunakan untuk mendeteksi kondisi cuaca kota Balikpapan dengan menggunakan listrik dari angin.

\section{Kesimpulan}

Berdasarkan hasil pengujian, pengukuran dan analisa yang telah dilakukan, diperoleh kesimpulan sebagai berikut :

1. Suhu terendah mencapai $25^{\circ} \mathrm{C}$, sedangkan suhu tertinggi mencapai $39^{\circ} \mathrm{C}$.

2. Kelembaban terendah sebesar $54 \%$, sedangkan kelembaban tertinggi sebesar $93 \%$.

3. Kecepatan angin sebesar $0,09 \mathrm{~m} / \mathrm{s}$, sedangkan kecepatan angin terrtinggi sebesar $5,73 \mathrm{~m} / \mathrm{s}$.

4. Hasil data sesuai dengan metode WMO.

5. Kondisi cuaca kota Balikpapan cenderung cerah.

\section{Daftar Pustaka}

Azmi, Mohamad. (2012). Sistem Cors (Continuously Operating Reference Station) di Indonesia dan di Beberapa Negara Lainnya, tersedia online di digilib.itb.ac.id/files/disk1/455/jbptitbpp-gdl-mohamadazm-22724-12012ta-r.pdf.

Badan Perencanaan Pembangunan Daerah. (2015). “Kajian Energi Terbarukan Di Kota Balikpapan”. Balikpapan : Pemerintahan Kota.

Gazeta, Rossiyskaya. (2014) 'Mengungkap Fakta GLONASS, GPS Versi Rusia', tersedia online di https://id.rbth.com/technology/2014/02/11/mengungkap_fakta_glonass_gps_versi_rusia_23181.

K. Karthik, T. Suraj, K. Lokesh, P. Arum, (2015) “Arduino Based Weather Monitoring System," International Journal of Engineering Research and General Science., Vol. 3, Issue $2:$ 452-458.

World Meteorological Organization. (2011). "World Meteorological Organization Instruments and Observing Methods Report No.106". Switzerland: Geneva 2.

Zalindri, Zeta Hanif, Darjat dan Munawar A.R. (2015) 'Rancang Bangun Mini Station Menggunakan Web Berbasis Arduino Atmega 2560’, Transient Journal, Vol. 4 No. 4 : 1079-1086. 